\title{
The Nature of Technology-Facilitated Violence and Abuse among Young Adults in Sub-Saharan Africa
}

\author{
Olusesan Ayodeji Makinde, Emmanuel Olamijuwon, \\ Nchelem Kokomma Ichegbo, Cheluchi Onyemelukwe, \\ and Michael Gboyega Ilesanmi
}

\begin{abstract}
Incidents of violence perpetrated through digital technology platforms or facilitated by these means have been reported, often in high-income countries. Very little scholarly attention has been given to the nature of technology-facilitated violence and abuse (TFVA) across sub-Saharan Africa (SSA) despite an explosion in the use of various technologies. We conducted a literature review to identify and harmonize available data relating to the types of TFVA taking place in SSA. This was followed by an online survey of young adults through the SHYad.NET forum to understand the nature of TFVA among young adults in SSA. Our literature review revealed various types of TFVA to be happening across SSA, including cyberbullying, cyberstalking, trolling, dating abuse, image-based sexual violence, sextortion, and revenge porn. The results of our online survey revealed that both young men and women experience TFVA, with the most commonly reported TFVA being receiving unwanted sexually explicit images, comments, emails, or text messages. Female respondents more often reported repeated and/or unwanted sexual requests online via email or text message while male respondents more often reported experiencing violent threats. Respondents used various means to cope with TFVA including blocking the abuser or deleting the abused profile on social media.
\end{abstract}

The Emerald International Handbook of Technology-Facilitated Violence and Abuse, 83-101 Copyright (C) 2021 Olusesan Ayodeji Makinde, Emmanuel Olamijuwon, Nchelem Kokomma Ichegbo, Cheluchi Onyemelukwe, and Michael Gboyega Ilesanmi

Published by Emerald Publishing Limited. This chapter is published under the Creative Commons Attribution (CC BY 4.0) licence. Anyone may reproduce, distribute, translate and create derivative works of these chapters (for both commercial and non-commercial purposes), subject to full attribution to the original publication and authors. The full terms of this licence may be seen at http://creativecommons.org/licences/by/4.0/legalcode. doi:10.1108/978-1-83982-848-520211005 
Keywords: Adolescents; internet; social media; sub-Saharan Africa; mobile phones; violence

\section{Introduction}

The utilization of technology, including cell phones, cameras, internet-associated gadgets, personal computers, and social media, has become part of regular dayto-day activities (Douglas, Harris, \& Dragiewicz, 2019; Gillwald, 2017; Henry \& Powell, 2018; Simon, Goldberg, Aharonson-Daniel, Leykin, \& Adini, 2014). These technologies are used for communicating and to carry out routine tasks. Africa's technology scene is fast-evolving, driven to a great extent by growth in cell phone penetration, which has become a significant tool for innovators beyond its basic use as a communication device. Today, Africa's continuous advancement in technology cannot be separated from the desire to solve its socioeconomic challenges (Eziakonwa, 2019). Cell phones brought new possibilities to Africa: connecting individuals and markets, and facilitating service delivery across the urban-rural divide (Aker \& Mbiti, 2011).

The overwhelming importance of the internet to development and the economy in the current information age cannot be overemphasized. In 2016, access to the internet was deemed a human right by the United Nations and the intentional disruption of internet, a human rights violation (Howell \& West, 2016). About $75 \%$ of respondents surveyed across 39 countries by Pew Research were found to either use the internet occasionally or own a smartphone (Poushter, Caldwell, \& Chwe, 2018a). Unlike more developed parts of the world where internet access is almost universal and the growth in use has plateaued, internet use in sub-Saharan Africa (SSA) ${ }^{1}$ has seen remarkable growth since 2013 (Silver \& Johnson, 2018a). In SSA, $41 \%$ of respondents utilize the internet across six countries surveyed (Silver \& Johnson, 2018a). Of these six countries, South Africa had the highest population with internet access, a median of $59 \%$. This was followed by Senegal (46\%), Nigeria (42\%), Ghana (39\%), Kenya (39\%), and Tanzania (25\%) (Silver \& Johnson, 2018a). The majority of internet users in SSA go online for social communication purposes (Silver \& Johnson, 2018a).

Paralleling the growth in use of the internet, the use of social media (such as Facebook, Instagram, and Twitter) has continued to see tremendous adoption in emerging and developing economies. The use of online social networking sites in these economies rose by $19 \%$ points from 34\% to 53\% between 2013 and 2018 (Poushter, Caldwell, \& Chwe, 2018b). In 2010, Facebook was the most visited website in Africa with more than 17 million subscribers (André-Michel, 2010). The population accessing Facebook from Africa had ballooned to more than 139 million users a month by 2018 , with the majority accessing it through their mobile devices (Shapshak, 2018). Social media has played important roles in sociopolitical discussions in the region such as during the "bring back our girls" campaign that was launched after more than 200 secondary school girls were kidnapped by Boko Haram insurgents in Nigeria (Peters, 2014). Twitter was used in coordinating the widespread condemnation and protests that followed to pressure the 
Nigerian government to act (Fink, Schmidt, Barash, Cameron, \& Macy, 2016). Twitter was also used for communication and coordination during the Westgate mall attack in Kenya, with researchers calling for a formal guideline on how to use these communication channels effectively in such emergency situations (Simon et al., 2014).

The internet has contributed to various facets of the economy in SSA, including education, health, agriculture, and communication (Silver \& Johnson, 2018b; Tom-Aba et al., 2015). In Tanzania, mobile phones have been used as surveillance tools for managing data from a rabies outbreak (Mtema et al., 2016). Similarly, in Malawi, people living with HIV and AIDS receive text messages daily via mobile phones reminding them to take their medicines on schedule (Aker \& Mbiti, 2011). In Nigeria, citizens can report domestic and sexual violence via phone calls or email (P.M. News, 2019), and in Ghana, farmers are able to find out the price of tomatoes in Accra, several kilometers away, via text message and decide whether it's worth ferrying their goods there for sale (Aker \& Mbiti, 2011). Also in Niger, laborers are able to call friends in Benin Republic to find out about job opportunities ahead of traveling there (Aker \& Mbiti, 2011).

African business owners are leveraging mobile phones to increase efficiency and delivery of services to consumers (Aker, 2010). The general availability of cell phones has paved the way for electronic banking (Donner \& Tellez, 2008). Mobile payment systems have emerged as a reliable alternative payment platform for transactions, consistently reducing the market share of cash-based transactions in national economies that once relied absolutely on cash payments (Aker \& Mbiti, 2011). Kenya launched M-PESA in 2007, "a mobile phone-based money transfer, financing, and microfinancing service to allow users to deposit, withdraw, transfer money and pay for goods and services" (Calvo, Morales, \& Zikidis, 2017, p. 127). M-PESA allows branchless banking service whereby users can withdraw money from a network of agents that includes airtime resellers and retail outlets acting as banking agents (Jack \& Suri, 2011). Between July 2016 and July 2017, 1.7 billion transactions were processed over M-PESA, totaling about 3.6 trillion shillings or $48.76 \%$ of the country's GDP (McGath, 2018). Thus, mobile technology has greatly affected the lives of the poor in Kenya and is noted to have lifted over 2\% of households out of poverty (Suri \& Jack, 2016).

Despite the many advantages of technology on a country's economy and populace (Silver \& Johnson, 2018b), there are emerging negative consequences of the use of technology that require additional investigation on their dimensions and consequences, and possible action to mitigate their effect (Douglas et al., 2019). Technology-facilitated violence and abuse (TFVA) has emerged as one of these consequences and has been increasingly studied in developed countries that birthed and embraced the widespread use of information and communications technology (ICT) long before SSA countries.

The rapid growth in the adoption of various technologies across SSA increases the number of people at risk for TFVA. The use of the World Wide Web and cell phones exposes new opportunities for perpetrators of violence to abuse their targets. Across the world, the number of reported cases of cyberbullying has been on the rise (Burton \& Mutongwizo, 2009). The unbound climes of the web equally 
make those accessing the internet from remote villages exposed to these risks. Hertz and David-Ferdon (2009) emphasize that the contemporary nature of electronic aggression limits the availability of information on the subject. However, available evidence is predominantly from the United States, Canada, the United Kingdom, Australia, and a few European countries.

Information relating to TFVA by race, ethnicity, gender, or location reveals TFVA's complexities. For example, although gender-based violence (GBV) is predominantly targeted at women, with at least one in three women having a lifetime experience of GBV (United Nations Population Fund, 2016), a large study conducted in Australia did not find significant differences between men's and women's reported experiences of TFVA (proportion of respondents who experienced at least one type of TFVA was $62.1 \%$ for women and $62.0 \%$ for men) (Powell \& Henry, 2019), although variations were observed to exist across the different dimensions of TFVA investigated in the study.

Pockets of research have been conducted in various parts of SSA that describe what has been observed by researchers within their immediate environment. However, we are not aware of any study of TFVA that encompasses the whole of SSA. The purpose of this chapter is to examine the different types of TFVA that have been recorded in SSA, with a particular focus on young adults. The first section provides background information in the form of a review of the current literature on TFVA in SSA. The second section sets out the methodology we used in conducting an online survey of young adults in SSA relating to their experiences with TFVA. The third section sets out the results of our online survey and discusses connections between our findings and the existing literature. Our conclusion summarizes these results and suggests directions for future research and policy.

\section{Literature Review}

In our review of current literature on TFVA in SSA, we found various studies that highlighted a range of issues around the topic across specific countries. We have grouped the issues discussed by these studies into three categories: (1) cyberbullying, cyberstalking, and trolling; (2) digital dating abuse and electronic dating violence; and (3) image-based sexual abuse (IBSA), sextortion, and revenge porn. It is noteworthy that these have been categorized for convenience, and there is no clear line separating one category from the other.

\section{Cyberbullying, Cyberstalking, and Trolling}

Cyberbullying is "bullying which involves the use of ICT such as email, cell phone and text messages, instant messaging, defamatory personal websites, and defamatory online personal polling websites to support deliberate, repeated, and hostile behavior by an individual or group that is intended to harm others" (Belsey, 2005, cited in; Burton \& Mutongwizo, 2009, p. 1). Cyberbullying has been widely reported across several countries in SSA including Botswana, 
Ethiopia, Ghana, South Africa, Senegal, Nigeria, Uganda, and others (Madanda, Ngolobe, \& Amuriat, 2009; Mooketsi, 2018; Mulisa \& Getahun, 2018; Olumide, Adams, \& Amodu, 2015b; Sall, 2017; Sam, Bruce, Agyemang, Amponsah, \& Arkorful, 2019). In one study, more than $45 \%$ of 18 - to 45 -year-old female users of Facebook or Twitter in West and Central Africa reported having experienced some form of GBV on social media (Internet Sans Frontieres, 2019). In 2010, the UN estimated that $95 \%$ of online "aggressive behavior, harassment, abusive language and denigrating images in online spaces were aimed at women and came from partners or former male partners" (APC, 2010, para 2). Burton and Mutongwizo (2009) reported that in South Africa, young people experienced cyberaggression within and outside the school premises, although this was more pronounced outside the school environment ( $42.9 \%$ vs. $31.0 \%)$. Various studies have shown that in Nigeria, about $40 \%$ of young people had experienced some form of cyberbullying, though many of them were also perpetrators (Olumide, Adams, \& Amodu, 2015a; Olumide et al., 2015b).

Cyberstalking involves the use of the internet or electronic devices to monitor a person's activity (Sissing, 2013), while internet trolling involves posting irritating comments, often to get others into an argument (Ansong, Takyi, Damoah, Ampomah, \& Larkotey, 2013). These types of abuse have equally been reported in different countries in the region including Ghana, Uganda, South Africa, and Nigeria (Ansong et al., 2013; Madanda, Berna, \& Amuriat, 2009; Punch Newspapers, 2020; Sissing, 2013). In Uganda, two women were murdered by their spouses after claiming they discovered romantic SMSs on their phones (APC, 2010; Madanda et al., 2009). In a recent incident reported in Nigeria, a woman was sentenced to death for killing her husband after finding nude pictures of another woman on his phone (Punch Newspapers, 2020).

\section{Digital Dating Abuse and Electronic Dating Violence}

Dating fraud is one of the most frequently discussed forms of TFVA in Africa. While Nigeria has been regularly accused of being the source of romance scams, leading such scams to be popularly referred to as "Nigerian scams," Edwards et al.'s (2018) analysis found several other African and non-African origins of such scams including Ghana, South Africa, Togo, Senegal, Ivory Coast, Kenya, Malaysia, the United Kingdom, the United States and Turkey. While most of the targets of the dating scams are women seeking companionship in developed countries, there are instances of men who are also tricked using various female profiles (Aransiola \& Asindemade, 2011). The mode of operation of the dating scams often involves long-term engagements with victims who fall in love believing such to be a mutual feeling. Unfortunately, many of the victims are tricked into parting with huge sums of money before realizing they were being scammed. Victims of dating scams are left with scars that end up affecting their psychological health. The consequences of dating scams could go beyond emotional and financial losses. In one instance, someone being scammed was convinced to travel to meet her supposed boyfriend based in West Africa. In the 
course of her visit, she was kidnapped by the boyfriend's gang and held by the group for ransom (Edwards et al., 2018).

There is also evidence of severe physical and sexual violence arising from internet-facilitated dating and intimate relationships in Africa. Five cases of women who met their abusers on Facebook or were reunited with them through this channel after not being in contact for a while have been chronicled in Nigeria. Two of the victims were raped while the other three were victims of attempted rape (Makinde, Odimegwu, Abdulmalik, Babalola, \& Fawole, 2016). One of the victims was murdered in the process while two others suffered severe physical violence. The victim who lost her life had traveled believing she was meeting with her boyfriend and his business partners based in Lagos (Idongesit, 2014). In another case, a young university undergraduate who first met with a young man on Facebook was pushed out of a third-floor apartment following an argument with him (Idongesit, 2014). While she did not die from her injuries, she suffered severe physical and life-changing injuries including a fractured pelvis (Idongesit, 2014).

\section{Image-Based Sexual Abuse, Sextortion, and Revenge Porn}

Technology-facilitated sexual violence (TFSV) is one form of TFVA. TFSV can include the use of technology to facilitate sexually violent physical encounters (as discussed above), as well as IBSA, sextortion, and revenge porn. IBSA is becoming a prevalent form of TFVA with the increasing availability of camera and video-enabled cell phones (Powell \& Henry, 2019). Often, images and videos are made with the consent of everyone involved. However, when the relationship goes sour, one of those involved may threaten to use the image against the other unless the other person meets some specified requests. IBSA can take many forms including sextortion and "revenge porn" (McGlynn, Rackley, \& Houghton, 2017). Sextortion is "the threatened dissemination of explicit, intimate, or embarrassing images of a sexual nature without consent, usually for the purpose of procuring additional images, sexual acts, money, or something else" (Patchin \& Hinduja, 2018, p. 2). Revenge porn is "the nonconsensual distribution of private, sexual images by a malicious ex-partner" (McGlynn et al., 2017, p. 26). There have been documented incidents of sextortion and revenge porn in Malawi, Uganda, Senegal, Nigeria, and South Africa (Chisala-Tempelhoff \& Kirya, 2016; Musoni, 2019; Sall, 2017). In Nigeria, a female university student was expelled after her boyfriend shared a sex video that they had both made at an earlier stage in their relationship (Vanguard News, 2019). Some research indicates that most of the denigrating sexual images available online feature women (APC, 2010).

Overall, there is relatively little research on TFVA generally or TFSV specifically in SSA. Only one identified study attempted to quantify the level of TFVA in the region, although its methodology was not adequately explained (Internet Sans Frontieres, 2019). Among available studies, various dimensions of TFVA have been recorded across the breadth of SSA, as outlined above, although incidents of TFVA and TFSV cannot be easily categorized as there is significant 
crossover among the various types. As a result, little is known about the nature and dimensions of TFVA and TFSV specifically in SSA as a whole, providing reason for additional investigation of these issues. Gaining a better understanding of these issues will be important for developing strategic advocacy, enactment of laws, and preventive action to respond to TFVA and TFSV in SSA.

\section{Methodology}

\section{Study Design and Recruitment}

We conducted an online survey between November 2019 and February 2020 in order to better understand experiences with various forms of TFVA (with a focus on TFSV) among young African adults between the ages of 18 and 34 . Respondents were recruited primarily through a paid advertisement on Facebook. Our team also shared the link to the survey on personal social media profiles and early respondents were encouraged to share the survey link with their friends. The Facebook advertisement environment provides potential advertisers a unique opportunity to target users on the platform based on a set of socio-demographic characteristics (such as age, sex, education, location), interests, or behaviors. Leveraging this opportunity, we initially created an advertisement campaign targeting Facebook users who were living in any SSA country at the time of data collection, were between ages 18 and 34 years, and whose primary language on Facebook was English. However, in order to increase female participation, after observing initially low responses from women, we created another campaign targeting young female adults. Both advertisements ran throughout the period of data collection.

The Facebook advertisements were delivered on the news feed of users whose profile matched our inclusion criteria. The advertisement caption described the survey as exploring the use of technology and adverse experiences that could occur from its use. The Facebook advertisement included a link to the survey website (SHYad.NET). SHYad.NET is an online collaborative platform by and for young African adults and is actively managed by one of the authors (EO). The platform was developed in 2018 as a data collection network for monitoring the sexual and reproductive health changes in young African adults.

Detailed information about the survey was provided on the SHYad.NET website. Respondents were informed that participation in the survey was voluntary and they could skip any question they did not want to answer. The contact details of one of the authors was also provided on the survey, and respondents were informed that they could get in touch via email should they require additional information about the survey.

\section{Instrument}

We combined several approaches to delineate experiences and coping strategies of TFVA among young adults in SSA countries. Respondents were asked about four 
forms of TFVA, of which many focused on specific forms of TFSV, as shown in the list below:

- digital harassment;

- image-based abuse;

- sexual aggression and/or coercion; and

- gender-/sexuality-based harassment. ${ }^{2}$

The TFSV questions were adapted from a dichotomous scale with a 21-item measure of TFSV from a previous study conducted by Powell and Henry (2019). The TFSV scale covered four different thematic areas: digital sexual harassment, IBSA, sexual aggression and/or coercion, and gender- and/or sexuality-based hate speech. There were different questions that addressed each of these four themes. Four questions that related to intimate partner technology-facilitated violence in the original scale were modified to reflect technology-facilitated violence perpetrated by anyone. For example, "Partner gained access to your emails or other online accounts without permission" was revised to "Someone gained access to your emails or other online accounts without permission."

Furthermore, respondents who reported having experienced any of the listed behaviors were asked to provide an additional narration of the circumstances of such experience. The respondents who reported having experienced any of the listed behaviors were also asked to describe how upsetting the experience was for them and how they handled the situation (coping strategies). The descriptions provided by the respondents were reviewed and categorized based on themes.

\section{Study Sample}

A total of 581 responses were received on the survey website as of February 28, 2020. During data collection, respondents were first asked to indicate whether they consented to participating in the study or not. The survey was subsequently terminated for the respondents who did not consent to participate in the survey. The survey website tracked the number of attempts made by a user to complete the questionnaire. We identified a few instances of multiple attempts to complete the survey by some users. However, the majority of the multiple attempts involved respondents who did not initially consent to participate in the study during the first attempt but consented prior to participating subsequently. For a few respondents who responded more than once, we carefully identified and excluded all subsequent responses during data analysis. Due to ethical reasons regarding the sampling of minors, we excluded responses from adolescents under 18 years at the time of data collection. We also excluded survey responses with missing information on key demographic characteristics such as age, sex, country of residence, and religious affiliation. These criteria resulted in the exclusion of about $32 \%$ of responses from those who did not provide consent to participate in the study, were taking the survey more than once, or did not meet any of the 
criteria highlighted. Our final analytic sample for the study comprised 389 complete responses from young adults aged 18-34 years who were resident in SSA.

\section{Ethical Considerations}

Ethical approval to collect responses on sexual and reproductive health using SHYad.NET was obtained from the University of the Witwatersrand Human Research Ethics Committee (nonmedical) under research ethics number H19/02/25 prior to recruiting respondents.

\section{Data Processing and Analysis}

We assessed experiences with TFVA based on the respondent's self-reported experience of the listed behaviors. The results were further stratified by gender to compare differences in the experiences of men and women. We then tested the observed differences across gender using Chi-square. A qualitative text analysis of respondents' description of any of the listed experiences was also conducted to provide a contextual description and explanation of the quantitative analysis of TFVA. Quotes from these descriptions were extracted and used to provide additional clarity to observations. Finally, we examined how the respondents handled their personal experience of any of the listed behaviors. Their described experiences were recoded into categorical groups to allow for proportional analysis. All data processing, analysis, and visualizations were done using $\mathrm{R}$ statistical package. $\mathrm{R}$ is an open source robust statistical package that is rich in conducting visualizations and enables manipulation of charts produced through the application in various dimensions. Its strength in visualization made it helpful in the analysis.

\section{Results and Discussion}

Table 5.1 presents the summary of descriptive characteristics of the sample. The respondents were drawn from 22 countries with one-third of respondents resident in Nigeria (34\%), 28\% in Kenya, and about 6\% in South Africa. The mean age of the respondents was 25 years $(\mathrm{SD}=4.94$ years). Respondents were mostly male $(64 \%)$ and the majority $(77 \%)$ had attained tertiary or higher education. More than three-quarters of the respondents were not married, although $43 \%$ were in a relationship. About $82 \%$ of the respondents were Christian and $14 \%$ were Muslim.

The high proportion of respondents from Nigeria, Kenya, and South Africa might have been influenced by the high penetration of internet in these countries (Silver \& Johnson, 2018a). More educated and affluent people are known to participate in surveys than people with lower levels of education (Bhutta, 2012; Smith, 2008). As such, it was unsurprising that the majority of the respondents in this study had higher educational qualifications. Past research on using Facebook as a recruitment platform also suggests that the Facebook advertising platform 
92 Olusesan Ayodeji Makinde et al.

Table 5.1. Descriptive Characteristics of Respondents.

\begin{tabular}{lc}
\hline Sociodemographic Characteristics & $\boldsymbol{N}=\mathbf{3 8 9}$ \\
\hline Age & $24.8(4.94)$ \\
Sex & \\
Female & $140(36.0 \%)$ \\
Male & $249(64.0 \%)$ \\
Education & \\
Tertiary & $91(23.4 \%)$ \\
Tertiary/Higher & $298(76.6 \%)$ \\
Country & \\
Ghana & $27(6.94 \%)$ \\
Kenya & $108(27.8 \%)$ \\
Nigeria & $133(34.2 \%)$ \\
South Africa & $23(5.91 \%)$ \\
Uganda & $29(7.46 \%)$ \\
Zambia & $24(6.17 \%)$ \\
Others & $45(11.6 \%)$ \\
Relationship Status & \\
Not married: not in relationship & $148(38.0 \%)$ \\
Not married: in a relationship & $169(43.4 \%)$ \\
Married or living with partner & $65(16.7 \%)$ \\
Formerly married & $7(1.80 \%)$ \\
Religious Affiliation & \\
Christian & $318(81.7 \%)$ \\
Muslim & $53(13.6 \%)$ \\
Others & $10(2.57 \%)$ \\
No religious affiliation & $8(2.06 \%)$ \\
\hline
\end{tabular}

tends to oversample better educated, young, and more active members (Rife, Cate, Kosinski, \& Stillwell, 2016). This category of people may also have easier access to the internet than their peers with lower levels of education and income.

\section{Reported Instances of Technology-Facilitated Violence and Abuse}

Table 5.2 presents the distribution of self-reported experience of any of the listed behaviors by gender. About $89 \%$ of males and $82 \%$ of females reported experiencing at least one of the listed behaviors. While more male respondents reported 
Table 5.2. Self-Reported Experience of Any Specific TFVA Among Respondents.

\begin{tabular}{lccc}
\hline & Experience of TFVA & No Experience of Any TFVA & $\boldsymbol{p}$ Value \\
\hline Sex & & & \\
Female & $115(82.1 \%)$ & $25(17.9 \%)$ & 0.073 \\
Male & $222(89.2 \%)$ & $27(10.8 \%)$ & \\
\hline
\end{tabular}

experiencing at least one of the listed behaviors, this difference was not statistically significant. This finding is similar to a study conducted in Australia that did not find an overall statistically significant difference across the proportion of men and women that had experienced at least one type of TFSV (Powell \& Henry, 2019).

\section{Type of Technology-Facilitated Violence and Abuse Experienced}

Fig. 5.1 presents the most common types of TFVA that our respondents reported having experienced. The results show that unwanted sexually explicit images, comments, emails or text messages were the most common types of TFVA experienced by the respondents. More than half $(56 \%)$ of the respondents (56\% females, $56 \%$ males) reported receiving unwanted sexually explicit images, comments, or text messages. A 24-year-old male respondent from South Africa described his experience as follows:

Someone unknown messaged me on Facebook and after I responded they started talking about sex and they (sent) nude pictures to me.

About $46 \%$ of the respondents reported receiving repeated and unwanted sexual requests online, via email or text message. We also found statistically significant evidence that female respondents $(54 \%)$ reported this behavior more often than male respondents $(42 \%)$ in the sample $\left(\chi^{2}=3.9283 ; p\right.$-value $=$ $0.0475)$. Less than $10 \%$ of respondents $(10 \%$ women and $9 \%$ men) reported having had an unwanted sexual experience with someone they met online. However, a 24-year-old female respondent from Uganda reported:

A guy I met online and pretended to be knowing me forced me into sex once. When he was requesting another time (more than once) I refused.

Close to one-third of the respondents reported that someone had gained access to their emails or other online accounts without permission. Men (33\%) more 


\section{Olusesan Ayodeji Makinde et al.}

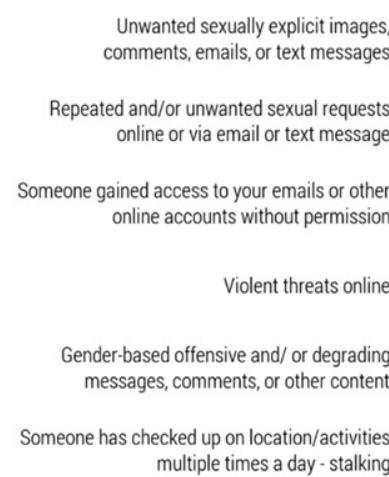

Someone has tried to watch or follow you from a distance, or spied on you with a mobile device (phone), listeningdevice, camera, or GPS [global positioning system]?

Someone publicly posted online an offensive sexual comment about you

Sexuality or sexual identity based offensive and/ or degrading messages, comments, or other content

Described or visually represented unwanted sexual act against you using an online/ email/messages

Image/video of an unwanted sexual experience taken-

Unwanted sexual experience with someone met online-

Nude or semi-nude image/video taken without permission-

Nude or semi-nude image/video posted online/sent onto others without permission

Someone posted personal details online saying you are available to have sex

Unwanted sexual experience with someone met dating site/app-

Image/video of an unwanted sexual experience posted online/sent onto others

Nude or semi-nude image/video threat to post online/send onto others

Described or visually represented unwanted sexual act against your avatar or game character

Image/video of an unwanted sexual experience threat to post online/send onto others

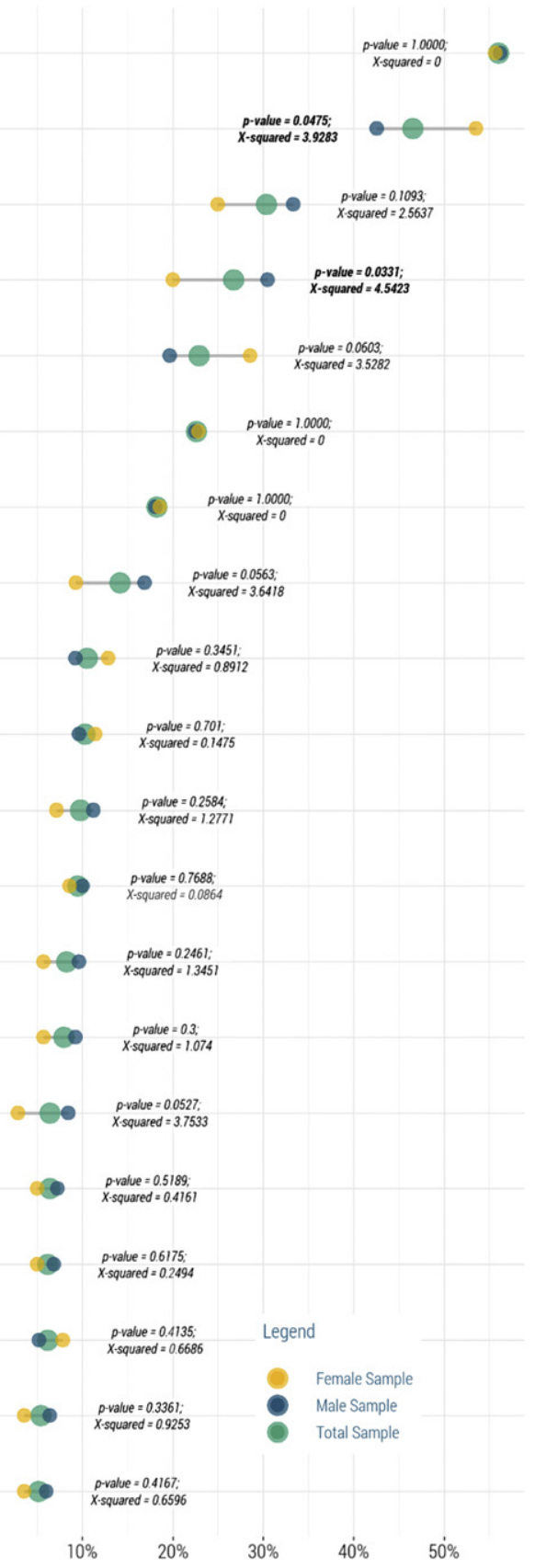

$10 \% \quad 20 \% \quad 30 \% \quad 40 \% \quad 50 \%$

Fig. 5.1. Experiences of Various Dimensions of TFVA by Gender. 
often reported this form of TFVA than women (25\%). However, this difference was not statistically significant. A 31-year-old male Nigerian noted that:

Someone hacked into my Facebook account and used the opportunity to request for financial assistance from my friends and family members.

About one-quarter $(27 \%)$ of the respondents reported experiencing a violent threat online. We observed a statistically significant $\left(\chi^{2}=4.5423 ; p\right.$-value $=$ $0.0331)$ difference in the online experience of violent threats between males $(33 \%)$ and females $(25 \%)$. A 33-year old male respondent from Kenya reported the following:

A fellow man was threatening to kill me and (was) sending abusive messages because he thought I was having (an) affair with her (his) wife.

Experiences of stalking $(23 \%)$ and spying (18\%) were also reported by the respondents. About one-fifth of respondents reported having had someone spy on them with a mobile device, listening device, camera, or GPS-enabled application. While we did not ask respondents whether the person stalking or spying on them was known to them, the concerning role that cyberstalking and tech-facilitated surveillance (e.g., by monitoring someone's phone messages) can play in intimate partner violence and homicide was graphically demonstrated in the murders of two Ugandan women discussed above (Madanda et al., 2009). And while studies of online stalking in other jurisdictions, such as Germany, indicate that victims are more likely to be women than men (Dreßing, Bailer, Anders, Wagner, \& Gallas, 2014), our findings indicated no statistically significant difference between men and women.

Overall, women were less likely than men to report having experienced a number of the listed behaviors, including sharing an image or video of an unwanted sexual experience, someone posting an offensive sexual comment about them, and someone gaining access to their emails or other online accounts. However, more women $(29 \%)$ reported having experienced genderbased offensive or degrading comments online than their male counterparts $(20 \%)$, although this difference was not statistically significant. The higher frequency reported is similar to an earlier study that suggested that women in West and Central Africa were more likely than men to be targeted by gender-related abuses (Internet Sans Frontieres, 2019). In fact, in our study, gender-related abuse was much higher in women than several other forms of abuse (see Fig. 5.1). Thus, bias against the female population in gender-related abuse may be a carryover to the digital space of the patriarchal norms of African societies, which are more tolerant of men than women (Albertyn, 2009; Makinde, Onyemelukwe, Onigbanjo-Williams, Oyediran, \& Odimegwu, 2017; Mudhai, Wright, \& Musa, 2016). 


\section{Coping Strategies for Technology-Facilitated Violence and Abuse}

As seen in Table 5.3, respondents who had experienced TFVA reported having used a number of strategies for coping with their experiences.

The most common approach for handling TFVA (which $32 \%$ of our respondents reported using) was reporting or employing the "block" option on the device, website, or app to avoid the perpetrator. For example, a 34-year-old female respondent from Nigeria reported the following:

I always block the person or sometimes shut down the account and put a red flag on it.

Five percent of respondents reported attending a counseling session with a close associate - such as a family member, friend, teacher, or clergy person, while $12 \%$ of respondents apologized to their contacts and changed their passwords after their profiles had been used to transmit messages wrongfully (see Table 5.3). As a 28-year-old male respondent from Uganda puts it:

I changed my Yahoo email password and emailed my contacts notifying them of (the) account having been hacked.

None of the respondents who had experienced one of the listed behaviors indicated that they had reported to the police or other security agencies for assistance. This might be a reflection of the gap in regulation of digital media in SSA and the limited action that internet users can take to seek redress when they have been violated online. An earlier study highlighted that the growth in ICT use in SSA has outpaced its regulatory framework, and this may have manifested in the strategies that respondents used to cope with abuse online (ChisalaTempelhoff \& Kirya, 2016). Similar challenges with policing IBSA have been reported in developed countries (Henry, Flynn, \& Powell, 2018). Thus, survivors of TFVA may be left with few options to seek redress when violated.

Table 5.3. Coping Strategies by Respondents.

\begin{tabular}{lcc}
\hline Description & Number of Responses & Proportion \\
\hline I went for counseling/prayed & 11 & $5 \%$ \\
I reported/blocked the offender & 77 & $32 \%$ \\
I did not respond & 44 & $19 \%$ \\
I deleted the account/messages & 34 & $14 \%$ \\
I apologized because my account & 28 & $12 \%$ \\
was hacked & 43 & \\
I took other actions & $\mathbf{2 3 7}$ & $\mathbf{1 0 0} \%$ \\
Total &
\end{tabular}




\section{Limitations}

Although our study contributes to literature in diverse ways, it is not without limitations. First is that respondents were recruited online using a nonprobabilistic sampling process, and our sample size was small. As a result, findings are not generalizable to the entire population of young SSA adults. Nevertheless, we believe that our study paves the way for future work in this area. Furthermore, while the risk of multiple submissions by an individual is a common limitation of studies using online samples, our study minimized this possibility using cookies already installed on the SHYad.NET website. This helped us to log and identify multiple responses from a single device, which were subsequently addressed at analysis, as noted above. Finally, as is typical of quantitative methodologies, while our online survey results provide an overview, they invite many additional questions about the context in which the reported incidents arose, including the gender of the perpetrator, their relationship to the victim, whether the incidents were isolated or part of a pattern of behavior, and what their impact was on the victim. These are the sorts of questions that could be pursued in future qualitative research.

\section{Conclusion}

Though not generalizable, it is notable that the overwhelming majority of young adults in our sample reported having experienced at least one of the listed forms of behavior often associated with TFVA. This is in keeping with the very limited existing research that has been conducted on the distribution and types of TFVA across the region. The young people in our study indicated experiencing different types of TFVA, with the most common being a form of TFSV: receiving unwanted sexually explicit images, comments, emails, or text messages. Overall, the vast majority of both young men and women respondents reported experiencing at least one form of TFVA, with the women respondents experiencing more sexual requests online and gender-based offensive and/or degrading comments and men respondents experiencing more online threats of violence. In terms of coping mechanisms, the fact that respondents were most likely to use the block option or delete their profiles, coupled with the fact that none of them indicated having reported their experiences to the authorities, may be suggestive of a number of things. It may be that they did not perceive the incident to have been serious enough to merit reporting and/or that they did not believe reporting would lead to any meaningful response. Future qualitative research could be effective for exploring both of these tentative explanations. The latter explanation would be consistent with suggestions by others, such as Chisala-Tempelhoff and Kirya (2016) and Facebook's Mark Zuckerberg (BBC News, 2020), that there are gaps in the regulatory framework for addressing online aggression that need to be addressed. However, there is a need for additional research to appropriately quantify the magnitude of TFVA generally and TFSV specifically across countries in the region in order to provide the evidentiary basis necessary to pave the way for interventions that will limit the impact that these new forms of violence may cause. Meaningfully addressing TFVA is particularly important in SSA as 
technology becomes more and more implicated in people's lives, and increasingly central to plans for economic growth and development.

\section{Notes}

1. SSA is the part of the African continent that lies south of the Sahara.

2. More detailed examples of the specific types of behavior respondents were asked about are depicted in Fig. 5.1, which is included in our Findings section below.

\section{References}

Aker, J. C. (2010). Information from markets near and far: Mobile phones and agricultural markets in Niger. American Economic Journal: Applied Economics, 2(3), 46-59.

Aker, J. C., \& Mbiti, I. M. (2011). Mobile phones and economic development in Africa. SSRN. Retrieved from https://papers.ssrn.com/sol3/papers.cfm?abstract_ $\mathrm{id}=1693963$. Accessed on January 10, 2020.

Albertyn, C. (2009). 'The stubborn persistence of patriarchy'? Gender equality and cultural diversity in South Africa. Constitutional Court Review, 2(1), 165-208.

André-Michel, E. (2010). A social media boom begins in Africa. Africa Renewal. Retrieved from https://www.un.org/africarenewal/magazine/december-2010/socialmedia-boom-begins-africa. Accessed on February 9, 2020.

Ansong, E. D., Takyi, T., Damoah, D., Ampomah, E. A., \& Larkotey, W. (2013). Internet trolling in Ghana. International Journal of Emerging Science and Engineering, 2(1), 42-43.

APC. (2010). How technology is being used to perpetrate violence against women - and to fight it. Johannesburg: APC.

Aransiola, J. O., \& Asindemade, S. O. (2011). Understanding cybercrime perpetrators and the strategies they employ in Nigeria. Cyberpsychology, Behavior, and Social Networking, 14(12), 759-763.

BBC News. (2020). Facebook boss calls for rules on harmful content. BBC News. February 15.

Belsey, B. (2005). Fair play at school - fair play in society towards a school without bullying! A manual for teachers and head teachers. Daphne Project. Retrieved from www.cyberbuying.ca/facts-st.html

Bhutta, C. B. (2012). Not by the book: Facebook as a sampling frame. Sociological Methods \& Research, 41(1), 57-88.

Burton, P., and Mutongwizo, T. (2009). Inescapable violence: Cyber bullying and electronic violence against young people in South Africa. Centre for Justice and Crime Prevention, 8, 12.

Calvo, S., Morales, A., \& Zikidis, Y. (2017). Social and solidarity economy: The world's economy with a social face. London: Taylor \& Francis.

Chisala-Tempelhoff, S., \& Kirya, M. T. (2016). Gender, law and revenge porn in subSaharan Africa: A review of Malawi and Uganda. Palgrave Communications, 2, 16069.

Donner, J., \& Tellez, A. (2008). Mobile banking and economic development: Linking adoption, impact, and use. Asian Journal of Communication, 18, 318-332. 
Douglas, H., Harris, B. A., \& Dragiewicz, M. (2019). Technology-facilitated domestic and family violence: Women's experiences. British Journal of Criminology, 59(3), 551-570.

Dreßing, H., Bailer, J., Anders, A., Wagner, H., \& Gallas, C. (2014). Cyberstalking in a large sample of social network users: Prevalence, characteristics, and impact upon victims. Cyberpsychology, Behavior, and Social Networking, 17(2), 61-67.

Edwards, M., Suarez-Tangil, G., Peersman, C., Stringhini, G., Rashid, A., \& Whitty, M. (2018). The geography of online dating fraud. In Workshop on technology and consumer protection (ConPro) (Vol. 7). San Francisco, CA: IEEE.

Eziakonwa, A. (2019). Can investing in Africa's tech generation change the future of development? UNDP in Africa. UNDP. Retrieved from https://www.africa. undp.org/content/rba/en/home/blog/2019/can-investing-in-africas-tech-generationchange-the-future-of-de.html. Accessed on January 13, 2020.

Fink, C., Schmidt, A., Barash, V., Cameron, C., \& Macy, M. (2016). Complex contagions and the diffusion of popular twitter Hashtags in Nigeria. Social Network Analysis and Mining, 6(1), 1-19.

Gillwald, A. (2017). Internet use barriers and user strategies: Perspectives from Kenya, Nigeria, South Africa and Rwanda. New York, NY: Mozilla Foundation.

Henry, N., Flynn, A., \& Powell, A. (2018). Policing image-based sexual abuse: Stakeholder perspectives. Police Practice and Research, 19(6), 565-581.

Henry, N., \& Powell, A. (2018). Technology-facilitated sexual violence: A literature review of empirical research. Trauma, Violence, \& Abuse, 19(2), 195-208.

Hertz, M. F., \& David-Ferdon, C. (2009). Electronic media and youth violence: A CDC issue brief for educators and caregivers. Atlanta, GA: Centerfor Disease Control and Prevention.

Howell, C., \& West, D. M. (2016). The internet as a human right. Brookings. Retrieved from https://www.brookings.edu/blog/techtank/2016/11/07/the-internet-as-a-humanright/. Accessed on February 10, 2020.

Idongesit, E. (2014). Youths, social media and gender-based violence: An emerging trend in Nigeria. International Journal of Economy, Management and Social Sciences, 3(1), 21-27.

Internet Sans Frontieres. (2019). \#IWD2019: Online gender-based violence affects $45 \%$ of women on social media in West and Central Africa. Internet Sans Frontières. Retrieved from https://internetwithoutborders.org/iwd2019-onlinegender-based-violence-affects-45-of-women-on-social-media-in-west-and-centralafrica/. Accessed on February 10, 2020.

Jack, W., \& Suri, T. (2011). Mobile money: The Economics of M-PESA. w16721. Cambridge, MA: National Bureau of Economic Research.

Madanda, A., Berna, N., \& Amuriat, G. Z. (2009). Uganda: Violence against women and information and communication technologies. Johannesburg: Association for Progressive Communications (APC).

Makinde, O. A., Odimegwu, C. O., Abdulmalik, J. O., Babalola, S. O., \& Fawole, O. I. (2016). Gender-based violence following social media acquaintance in Nigeria. African Journal of Reproductive Health, 20(4), 67-76.

Makinde, O. A., Onyemelukwe, C., Onigbanjo-Williams, A., Oyediran, K. A., \& Odimegwu, C. O. (2017). Rejection of the gender and equal opportunities bill in Nigeria: A setback for sustainable development goal five. Gender in Management: An International Journal, 32(3), 234-240. 
McGath, T. (2018). M-PESA: How Kenya revolutionized mobile payments. Medium. Retrieved from https://mag.n26.com/m-pesa-how-kenya-revolutionized-mobilepayments-56786bc09ef. Accessed on February 10, 2020.

McGlynn, C., Rackley, E., \& Houghton, R. (2017). Beyond 'revenge porn': The continuum of image-based sexual abuse. Feminist Legal Studies, 25(1), 25-46.

Mooketsi, B. (2018). An investigation on the prevalence of cyberbullying amongst undergraduate students in the University of Botswana. Mosenodi Journal, 21(2), 44-54.

Mtema, Z., Changalucha, J., Cleaveland, S., Elias, M., Ferguson, H. M., Jo, E., ... Hampson, K. (2016). Mobile phones as surveillance tools: Implementing and evaluating a large-scale intersectoral surveillance system for rabies in Tanzania. PLoS Medicine, 13(4), e1002002.

Mudhai, O. F., Wright, B., \& Musa, A. (2016). Gender and critical media-information literacy in the digital age: Kenya, South Africa and Nigeria. Journal of African Media Studies, 8(3), 267-280.

Mulisa, F., \& Getahun, D. A. (2018). Perceived benefits and risks of social media: Ethiopian secondary school students' perspectives. Journal of Technology in Behavioral Science, 3(4), 294-300.

Musoni, M. (2019). The criminalization of 'revenge porn' in South Africa: Research. Obiter, 40(1), 61-74.

Olumide, A. O., Adams, P., \& Amodu, O. K. (2015a). International note: Awareness and context of cyber-harassment among secondary school students in Oyo state, Nigeria. Journal of Adolescence, 39, 10-14.

Olumide, A. O., Adams, P., \& Amodu, O. K. (2015b). Prevalence and correlates of the perpetration of cyberbullying among in-school adolescents in Oyo state, Nigeria. International Journal of Adolescent Medicine and Health, 28(2), 183-191.

Patchin, J. W., \& Hinduja, S. (2018). Sextortion among adolescents: Results from a national survey of US Youth. Sexual Abuse, 32(1), 30-54. doi:10.1177/107906 3218800469

Peters, M. A. (2014). 'Western education is sinful': Boko Haram and the abduction of chibok schoolgirls. Policy Futures in Education, 12(2), 186-190.

P.M. News. (2019). How to report sexual \& child abuse, domestic violence in Nigeria. P.M. News. Retrieved from https://www.pmnewsnigeria.com/2019/06/28/how-toreport-sexual-child-abuse-domestic-violence-in-nigeria/. Accessed on January 20, 2020.

Poushter, J., Caldwell, B., \& Chwe, H. (2018a). Across 39 countries, three-quarters say they use the internet. Pew Research Center's Global Attitudes Project. Retrieved from https://www.pewresearch.org/global/2018/06/19/across-39-countries-three-quarterssay-they-use-the-internet/. Accessed on February 9, 2020.

Poushter, J., Caldwell, B., \& Chwe, H. (2018b). Social media use continues to rise in developing countries. Pew Research Center's Global Attitudes Project. Retrieved from https://www.pewresearch.org/global/2018/06/19/social-media-use-continuesto-rise-in-developing-countries-but-plateaus-across-developed-ones/. Accessed on February 9, 2020.

Powell, A., \& Henry, N. (2019). Technology-facilitated sexual violence victimization: Results from an online survey of Australian adults. Journal of Interpersonal Violence, 34(17), 3637-3665. 
Punch Newspapers. (2020). Maryam Sanda sentenced to death for killing husband. Punch Newspapers. Retrieved from https://punchng.com/maryam-sanda-sentencedto-death-for-killing-husband/. Accessed on February 12, 2020.

Rife, S. C., Cate, K. L., Kosinski, M., \& Stillwell, D. (2016). Participant recruitment and data collection through Facebook: The role of personality factors. International Journal of Social Research Methodology, 19(1), 69-83.

Sall, O. (2017). The impact of social and digital medias on Senegalese society. Studies in Media and Communication, 5(2), 1-7.

Sam, D. L., Bruce, D., Agyemang, C. B., Amponsah, B., \& Arkorful, H. (2019). Cyberbullying victimization among high school and university students in Ghana. Deviant Behavior, 40(11), 1305-1321.

Shapshak, T. (2018). Almost all of Facebook's 139 million users in Africa are on mobile. Forbes. Retrieved from https://www.forbes.com/sites/tobyshapshak/2018/ 12/18/almost-all-of-facebooks-139m-users-in-africa-are-on-mobile/. Accessed on February 9, 2020.

Silver, L., \& Johnson, C. (2018a). Internet use growing across sub-Saharan Africa, but most are still offline. Pew Research Center's Global Attitudes Project. Retrieved from https://www.pewresearch.org/global/2018/10/09/internet-use-is-growing-acrossmuch-of-sub-saharan-africa-but-most-are-still-offline/. Accessed on February 9, 2020.

Silver, L., \& Johnson, C. (2018b). Sub-saharan Africans say internet use has positively impacted education, personal relationships and economy. Pew Research Center's Global Attitudes Project. Retrieved from https://www.pewresearch.org/global/2018/ 10/09/sub-saharan-africans-say-internet-use-has-positively-impacted-education-per sonal-relationships-and-economy/. Accessed on February 9, 2020.

Simon, T., Goldberg, A., Aharonson-Daniel, L., Leykin, D., \& Adini, B. (2014). Twitter in the cross fire - the use of social media in the Westgate mall terror attack in Kenya. PloS One, 9(8), e104136.

Sissing, S. K. (2013). A criminological exploration of cyber stalking in South Africa. Ph.D. thesis. University of South Africa, Pretoria.

Smith, G. (2008). Does gender influence online survey participation?: A record-linkage analysis of university faculty online survey response behavior. ERIC Document Reproduction Service No. ED 501717.

Suri, T., \& Jack, W. (2016). The long-run poverty and gender impacts of mobile money. Science, 354(6317), 1288-1292.

Tom-Aba, D., Olaleye, A., Olayinka, A. T., Nguku, P., Waziri, N., Peter, A., ... Shuaib, F. (2015). Innovative technological approach to ebola virus disease outbreak response in Nigeria using the open data kit and form hub technology. PloS One, 10(6), e0131000.

United Nations Population Fund. (2016). Gender-based violence. UNFPA - United Nations Population Fund. Retrieved from http://www.unfpa.org/gender-basedviolence. Accessed on February 11, 2016.

Vanguard News. (2019). Babcock university expels girl in viral sex tape video. Vanguard News. Retrieved from https://www.vanguardngr.com/2019/11/babcockuniversity-expels-girl-in-viral-sex-tape-video/. Accessed on February 10, 2020. 